\begin{tabular}{rr} 
çağdaş & Yaratıcı Drama Dergisi 2015, 10(2), 165-174 \\
drama & www.yader.org \\
\hline
\end{tabular}

\title{
Yaratıcı Drama Yöntemiyle Okul Öncesi Çocuklarının İliş̧ki Başlatma ve Sürdürebilme Becerilerinin Geliştirilmesi
}

\author{
Keziban Ökten ${ }^{1}$
}

Ö. Özlem Gökbulut ${ }^{2}$

\begin{tabular}{l}
\hline Makale Bilgisi \\
\hline DOI: 10.21612/yader.2015.014 \\
\hline Anahtar Sözcükler \\
Okul öncesi \\
Yaratıcı drama \\
Sosyal beceriler
\end{tabular}

\begin{abstract}
Öz
Birey, içinde yaşadı̆̆ toplumun bir üyesidir ve diğer insanlarla birlikte yaşamak durumundadır. Birlikte yaşayabilmek için etkili iletişim kurabilmek ve sosyal kabulü olan davranışlar sergilemek gibi bir takım becerilere sahip olmak gereklidir. Sosyal beceriler olarak adlandırılan bu beceriler sayesinde insanlar bulundukları topluma uyum sağlar. Okul öncesi dönemde çocuklar, başka çocuklarla oynamaya, karşılıklı konuşmaya, iletişim kurmaya başlarlar yani sosyalleşirler. Çocuğun kendini rahatça ifade edebilmesi, haklarını savunabilmesi, ailesi ve çevresindeki bireylerle ilişki kurabilmesi, bulunduğu ortamda kabul edilmesi, onun gelecekte olumlu ilişkiler kurmasına, uyumlu ve mutlu bir birey olmasına olanak sağlayacaktır. Bunun için sosyal becerilere sahip olmaları, bu becerilere sahip olmayan çocuklara ise bu becerilerin kazandırılması gerekmektedir. Bu çalıșma, okul öncesi dönem çocuklarına yaratıcı drama yöntem ve teknikleri kullanilarak sosyal becerilerden, ilişki başlatma ve sürdürebilme becerilerinin geliştirilmesi amacıyla yapılmıştır.

Çalışmada, sihirli bir kasaba ve bu kasabada yaşayan oyuncu teyze karakterinden yola çıkılarak atölyeler tasarlanmıştır. Yönerge alma, yönerge verme, kendini ve başkalarını tanıtma, dinleme, soru sorma, konuşmayı başlatma ve sürdürebilme, yardım isteme, bir gruba katılma, ikna etme, teşekkür etme, iltifat etme, özür dileme becerilerinin geliştirilmesine yönelik uygulamaların yapıldığ yaşayan kişiler, çeşitli kostüm ve aksesuarlar kullanılarak çocukların ve liderin role girmesiyle, canlandırmalar ve doğaçlamalarla işlenmiştir. Çalışma, 5 yaşında $5 \mathrm{klz}$, 3 erkek olmak üzere toplam 8 çocuk ile Özel Çakır Eğitim Kurumları'nın drama sinıfinda gerçekleştirilmiştir.
\end{abstract}

Araştırma süresince veri toplama araçları olarak; odak grup görüşmesi, veli anketi, öğretmen gözlem kayıtları kullanılmıştır. Odak grup görüşmesinde, atölye çalışmalar başlamadan önce, çocukların sosyal beceri davranışlartyla ilgili veli görüşlerinin elde edilmesi sağlanmıștır. Velilere uygulamadan önce ve sonra, Inanç Eti(2010) 'nin "Iliş̧kiyi Başlatma ve Sürdürebilme Becerisi Veli Anketi" uygulanmıştır. Uygulamadan önce yapılan veli anketi ile çocukların ilişkiyi başlatma ve sürdürebilme becerisi davranışlarıyla ilgili hazır bulunuşluklarının fark edilmesi, uygulamadan sonra yapılan veli anketi ile çocukların bu davranışlarında uygulama süresince bir değişme olup olmadığının gözlemlenmesi amaçlanmıştır. Öğretmen gözlem kayıtlarıyla, atölyeler uygulanırken yaşanan olumlu ve olumsuz durumların belirlenerek çalışma sonrasında neler yapıldı ̆̆ ve başka neler yapılabileceğiyle ilgili görüşlerin belirtilmesi amaçlanmıştır. Çalışma sonunda yaratıcı drama yöntemi kullanılarak gerçekleştirilen etkinliklerin çocukların sosyal becerilerden ilişki başlatma ve sürdürebilme becerilerinin geliştirilmesinde etkili olduğu belirlenmiştir.

$1 \quad$ Drama Lideri, E-posta: kezbanokten@gmail.com

2 Bil. Uzm. Öğretmen. Milli Eğitim Bakanlığı. E-posta: ooozlemgokbulut@gmail.com 


\section{Developing the Skills of Preschool Children in Building and Sustaining Relationships with the Creative Drama Method}

\begin{tabular}{l} 
Article Info \\
\hline DOI: $10.21612 /$ yader.2015.014 \\
\hline Keywords \\
Preschool \\
Creative drama \\
Social skills
\end{tabular}

\begin{abstract}
Children in preschool period start to play, talk and communicate with other children, which means they socialize. Children's abilities to express themselves easily, defend their rights and build relationships with their families and the people around them, be accepted in the environment they are in will enable them to build positive relationships in the future and become conformist and happy individuals. For this purpose, children need to have social skills; those who do not have these skills need to gain them. This study was performed to develop the skills of preschool children in building and sustaining relationships among social skills by using the creative drama method and techniques.
\end{abstract}

In this study, workshops were carried out based on a magical town and a playful old woman character living in this town. The practices for the development of skills such as giving instructions, introducing oneself and the others, listening, questioning, starting and continuing a conversation, asking for help, joining a group, persuading, thanking, complimenting and apologizing were conducted in the workshops. Moreover, animations and improvisations were performed with the impersonation of children and leaders by using the people living in the town, various costumes and accessories. The project was carried out with a total of eight children; five girls and three boys at the age of five, in the drama class of Private Çakır Educational Institution. Focus group interviews, parent questionnaires, and teacher observation records were used as data collection tools during the project. Before the workshop practices, the parent observations on the social skill behaviors of children were obtained in the focus group interviews.

"The Parent Questionnaire on the Skill of Building and Sustaining Relationship" prepared by Eti (2010) was implemented to the parents before and after the practice. With the parent questionnaire implemented before the practice, it was aimed to recognize the readiness of children concerning their skill of building and sustaining relationships, and with the parent questionnaire implemented after the practice, it was aimed to observe whether there would be a change in children's behaviors during the practice. With the teacher observation records, it was aimed to indicate the opinions related to what has been done and what else can be done after the project by identifying positive and negative situations experienced during performing workshops. As a result of this study, it has been revealed that the activities performed by using the creative drama method is effective on the skills of children in building and sustaining relationships among social skills.

\section{Giriş}

Bireyin içinde yaşadığ toplumun üyesi durumuna gelmesine sosyalleşme süreci denir. Gerçekte bu süreç, bireyin çevresiyle iletişim ve etkileşiminin bir sonucudur. Yaşam boyu sürer ve bireye yeni yaşantılar kazandırır (Cerrahoğlu, 2002, s.1). Kişinin güvenilir, dürüst, tutarlı, yardım sever, yiğit, cömert, insanlık idealine bağlı, özverili, yaratıcı, zekasını insanlığın hizmetine adayan bir insan olması ya da bencil, hırsl1, tutarsız, hilekar, cimri, yalanc1, korkak biri olması bu özelliklerin bir bölümünü, belki çoğunu kişiliğinin bir parçası haline getirmesi, sosyalleşmesi sonucudur (Köknel'den akt. Cerrahoğlu, 2002, s.4)

Sosyalleşme süreci, bireyin hayatı boyunca devam eder. Sosyalleşme sürecinde yaşanılan her şey, bireyin karakterinin ve kişiliğinin oluşmasına etki eder. Bu da bize, içinde bulunduğumuz toplumda uyumlu, tutarlı, sağlam karaktere sahip bireyler yetiştirebilmemizi sağlayabilecek olan bu sürecin önemini göstermektedir. 
Bireyin sosyal kabulü olan davranışlar sergilemesi ve etkili iletişim kurabilmesi için bir takım beceriler edinmesi gereklidir. Sosyal beceriler olarak adlandırılan bu beceriler sayesinde insanlar bulundukları topluma uyum sağlar. (Erbay, 2008, s.10).

Sosyal beceriler, bireylerin birbirleriyle olan iletişim ve etkileşimlerini etkileyen, toplum içinde kabul görülme veya görülmeme durumlarına gerekçe oluşturan davranışları kapsar. Çocukların bireysel özelliklerine bağlı olarak; bazı çocuklar bu davranışları göstermede hiç problem yaşamazken, bazı çocukların ise davranış yönetiminde zorlandığı, sosyal becerilerinde ve gelişiminde desteklenmeye ihtiyaç duydukları gözlemlenmektedir. Sosyal beceriler konusunda gelişime ve desteklenmeye ihtiyaç duyan çocuklar, gelecekte yaşamlarının farklı dönemlerinde ve farklı rollerde de ilişkilerde problemler yaşayabilmektedirler. Gelecekte çocukların, okul öncesi dönemden itibaren sosyal beceri eğitimleri verilerek sosyal beceri düzeylerinin yükseltilmesi sayesinde, daha sağliklı kişilikler geliştirecekleri düşünülmektedir.

İçinde bulunulan sosyal ortama uygun davranma yeteneği olarak tanımlanan sosyal beceriler, kişilerarası ilişkilerin kurulmasında ve sosyal amaçların gerçekleştirilmesinde çok önemli rol oynarlar. Bu beceriler, kişinin olumlu ya da olumsuz duygularını uygun bir şekilde anlatabilmesini, kişisel haklarını savunabilmesini, gerektiğinde başkalarından yardım isteyebilmesini, kendisine uygun olmayan istekleri geri çevirebilmesini kolaylaştırır (Avcıŏglu, 2007, s.88).

Okul öncesi eğitimde, sosyal beceri ve becerilerin öğretimi veya eğitimine yönelik çalışmaların olumlu etkileri olduğunu saptayan araştırmaların sayısı oldukça fazladır. Avcığlu (2003)'nun “Okul Öncesi Dönemdeki Çocuklarda Sosyal Becerilerin Öğretilmesinde İşbirlikçi Öğrenme Yöntemi ile Sunulan Öğretim Programının Etkililiğinin İncelenmesi” isimli çalışmasında, sosyal beceri eğitiminin çocukların dinleme, sözel açıklama ve kişiler arası ilişkilere yönelik becerilerinde artışa neden olduğu kaydedilmiştir. Kurt (2007), okul öncesi eğitim kurumlarına devam eden beşaltı yaş çocuklarının sosyal uyum ve becerilerine proje yaklaşımlı eğitim programlarının etkisinin incelenmesi çalışmasında, sosyal uyum ve becerilerin desteklendiği eğitim programları ile çocukların sosyal becerileri tanıma ve uygulama yetilerini kazanmaları sağlanabilir yorumunu yapmıştır. Çubukçu ve Gültekin, "İlköğretimde Çocuklara Kazandırılması Gereken Sosyal Beceriler” isimli araştırmalarının sonucuna göre ilköğretim öğretmenlerinin en çok puan verdikleri sosyal beceri alanı "ilişkiyi başlatma ve sürdürme becerileri” olduğunu ortaya koymuşlardır (Çubukçu ve Gültekin, 2006, s.161). Aslan (2008), “Drama Temelli Sosyal Beceri Eğitimi’nin 6 Yaş Çocuklarının Sosyal İlişkiler ve İşbirliği Davranışlarına Etkisi” isimli yüksek lisans tezinde, "Olumlu İlişkileri Sürdürme” ve "Grupla İlişkileri Sürdürme" davranışlarıyla ilgili son test puan ortalamaları arasında, deney grubu lehine anlamlı düzeyde bir farklılık olduğunu saptamıştır. Phillipsen, Bridges, McLemore ve Saponaro (1999), yaptıkları araştırmada çocukların ve ebeveynlerin görüşlerine göre arkadaşlık becerisinin akran kabulü ile ilişkili olduğunu ve öğretmenlerin düşüncelerine göre, arkadaş kabulü ne kadar fazla ise geri çekilmenin ve utangaçlığın o kadar düşük olduğunu saptamışlardır.

Gresham, çocukluk döneminde sosyal becerilerde yetersizlikleri nedeniyle yaşıtları tarafindan kabul edilmeyen ve bu nedenle yalıtılmış olan bireylerin yetişkinlik döneminde alkol kullanımında aşırılık, suç işleme oranında artış, arkadaş edinmede güçlük, boşanma ve işsizlik, gibi sosyal sorunlar yaşadıklarını belirtmiştir (Çifci ve Sucuoğlu, 2009, s.27)

Okulöncesi dönem çocukların, kişilik ve sosyal gelişimleri açısından önemli bir dönemdir. Bu dönem çocukların başka çocuklarla oynamaya, karşı1ıklı konuşmaya, iletişim kurmaya başladıkları, 
sosyalleştikleri bir dönemdir. Sosyal becerilere sahip çocuklar; paylaşımcı, özgüvenli, problem çözme becerisine sahip ve akranları tarafından kabul edilen çocuklardır. Ladd'e (1990) göre; akranlar tarafından reddedilme çocukların yaşayabileceği en zor duygusal ve sosyal deneyimdir ve çocukları en olumsuz etkileyen konulardan biri akranlar tarafından dışlanmaktır (Harrist ve Bradley, 2003, s.186). Bulunduğumuz toplumlarda kabul edilebilmek için sosyal kabulü olan davranışlar sergilememiz gerekmektedir. Sosyal beceriler de sosyal kabulü olan davranışlardır.

Yapılan araştırmaların sonuçlarına göre; sosyal beceriler öğretilebilir olduğu için, sosyal beceri eğitimleri erken yaşta bireylere verildiğinde, sosyal gelişimleri ve akademik performansları yüksek bireylerin oluşturduğu bir topluma sahip olunabileceği, kazandırılan davranışların kalıcı olacă̆ 1 , kişiler arası ilişkilerde problemlerin en aza indirilebileceği ve dolayısıyla kendine olan güvenin artmasına olanak tanıyacağı görülmektedir.

Ülkemizde okul öncesi eğitim çalışmalarında, günümüzde sosyal beceri eğitimine daha fazla önem verilmektedir. Okul öncesi eğitmenlerinin sayıca az olması ve okul öncesi eğitimin yakın zamana kadar zorunlu olmaması, öğretilecek olan sosyal beceri eğitiminin istenilen düzeyde yapılamamasına neden olmuştur. Gelecekte bu konuda daha olumlu gelişmeler sağlanacağı, bunun için biraz zamana ihtiyaç olduğu görülmektedir.

Bireyler arasındaki öğrenme farklılıklarını göz önünde bulunduracak, doğru hazırlanmış, örnek davranışların sergileneceği öğrenme yöntem ve teknikleriyle hazırlanacak sosyal beceri eğitimlerinin, okul öncesi dönemden başlayarak çocuklara verilmesinin, belirginleşmeyen kimlikler, oturmamış değerler ve ülke işleyişindeki temel sistemleri olumlu yönde etkileyeceği görülmektedir. Çocuklara bu davranışları kazandırabilmek için, çeşitli yöntemler kullanılır. Kullanılacak olan öğrenme yöntemi, çocuğun öğrenmesini kolaylaştırmalı, sürece aktif olarak katılmasını sağlamalı, çocuğu devamlı güdülemeli, yaparak yaşayarak öğrenmesi ve yaratıcılığının geliştirilmesine olanak tanımalıdır. Kara ve Çam (2007)'ın “Yaratıcı Drama Yönteminin Bazı Sosyal Becerilerin Kazandırılmasına Etkisi” adlı çalışmalarında, yaratıcı drama yönteminin, bireyin toplumsallaşmasında önemli katkılarının olduğunu söylemişlerdir. Toplumsallaşmanın sağlanmasında sosyal beceriler önemli bir yer tutmaktadır.

Toplumun gelişmesine katkıda bulunmak, cinsiyet, dil, din, ırk ayrımı yapmadan, çocuğu dinleyici konumundan çıkarıp, kazandırmaya çalışılan davranışla ilgili konuları, bedenini ve duyu organlarını kullanarak canlandırıp, yaşayarak öğrenmesi amacı doğrultusunda en uygun öğretim yönteminin yaratıcı drama olduğu düşünülmektedir. Yaratıcı drama, katılımcıları birlikte düşünmeye ve hissetmeye sevk eder. Birey özgürce kendini ifade edebilir; yargılanma, eleştirilme, suçlanma korkusu yoktur.

$\mathrm{Bu}$ çalışmada sosyal becerilerden "İlişki başlatma ve sürdürebilme becerilerinin" öğretilebilmesi hedeflenmektedir. Konunun yaratıcı drama ile işlenmesinin nedeni; çocuğu dinleyici konumundan çıkarıp, kendini özgürce ifade edebileceği, duygu ve düşüncelerini eyleme dönüştürebileceği, yaparak, yaşayarak, hayal gücünü kullanarak, yaratıcılığını işin içine katıp, duyumsayarak, deneyerek öğreneceği bir ortam sağlamasıdır. Sosyal becerilerden İlişki başlatma ve sürdürebilme becerilerinin kazandırılmasına yönelik etkinliklerin, çocukların aileleri, arkadaşları ve çevreleriyle olan ilişkilerinde bugün ve yarın başarılı bireyler olmalarına temel olması açısından katkı sağlayacağı düşünülmektedir. 


\section{Yöntem}

\section{Çalışmanın Modeli}

Araştırmanın modeli durum (örnek olay) çalışması olarak belirlenmiştir. Durum çalışması: (1) güncel bir olguyu kendi gerçek yaşam çerçevesi (içeriği) içinde çalışan, (2) olgu ve içinde bulunduğu içerik arasındaki sınırların kesin hatlarıyla belirgin olmadığı ve (3) birden fazla kanıt veya veri kaynağının mevcut olduğu durumlarda kullanılan, görgül bir araştırma yöntemidir (Yin, 1984'den akt.Yıldırım ve Şimşek, 2011)

\section{Veri Toplama Araçları}

$\mathrm{Bu}$ çalışmada veri toplama aracı olarak odak grup görüşmesi, öğretmen gözlem kayıtları ile “İlişki başlatma ve sürdürebilme becerisi veli anketi” kullanılmıştır.

Atölye çalışmalarının öncesinde; 8 velinin katıldığı, 47 dakika süren odak grup görüşmesi aracılığıyla çocuklarının ilişki başlatma ve sürdürebilme becerilerine sahip olup olmadığı ile ilgili görüşme yapılmış ve bu konuya ilişkin görüşlerinin alınması amaçlanmıştır. Bu maksatla velilere sorulan sorulardan bazıları şu şekildedir:

- Çocuğunuzu sosyal davranışlar konusunda yeterli görüyor musunuz?

- Çocuğunuz girdiği ortamda hemen arkadaş edinebiliyor mu?

- Çocuğunuz arkadaşları tarafından etkinliklere davet ediliyor mu?

Atölye sürecinde öğretmen gözlem kayıtlarıyla, öğretmenin atölye süresince, düzenli olarak yapmış olduğu gözlemleri ve yazdığı değerlendirmeleri kayıt altına alınmıştır.

Eti (2010)'nin “Drama Etkinliklerinin Okul Öncesi Eğitim Kurumuna Devam Eden 5-6 Yaş Grubu Çocukların Sosyal Beceriler Üzerine Etkisi” adlı yüksek lisans tezinde uyguladığı, toplam on üç kişiden oluşan uzman görüşüne sunarak, incelenmesini sağlayıp, düzenlemiş olduğu "İlişkiyi Başlatma ve Sürdürebilme Becerisi Veli Anketi” atölye çalışmaları öncesi ve sonrasında uygulanarak iki anket arasındaki farklar değerlendirilmiştir.

\section{Verilerin Çözümlenmesi}

Odak grup görüşmesinde sorulan sorulara verilen cevaplar sınıflandırılarak, çocukların sosyal beceri davranışlarıyla ilgili velilerin gözlemleri alınmıştır. Çalışma öncesi ve sonrasında uygulanan "İlişki başlatma ve sürdürebilme becerisi" anketinde, her zaman, bazen, hiçbir zaman derecelendirme ifadeleriyle, sosyal beceriye giren eylemlerden ne kadarının davranışa dönüştüğü kodlanmış, ön anket ve son anket arasındaki farklar belirlenmiştir. Öğretmen gözlem kayıtlarıyla, atölyeler uygulanırken yaşanan olumlu ve olumsuz durumlar belirlenerek, proje sonrasında, neler yapıldığı ve başka neler yapılabileceğiyle ilgili görüşler belirtilmiştir.

\section{Bulgular}

\section{Görüşmelere İlişkin Bulgular}

Çalışma kapsamında velilerle gerçekleştirilen odak grup görüşmesinde sorulan sorulara verilen yanıtlar aşağıda gösterilmiştir. 
Kendilerini tanıtmaları istenen ilk soruya verilen cevaplardan, bütün velilerin eğitim ve sosyoekonomik düzeylerinin yüksek olduğu fark edilmiştir. Velilerden çocuklarını iki üç cümle ile açıklamaları istendiğinde; dört veli çocuklarının çekingen davranışlar sergilediğini, üç veli çocuklarının uyumlu ve hassas, bir veli kuralcı olduğunu, başka bir veli ise çocuğunun inatçı ve çabuk demoralize olduğunu söylemiştir. Buradan çocukların sosyal beceri davranışlarını göstermeleri açısından desteklenmesinin yararlı olacağı sonucuna ulaşılmıştır. Açılamalardan, çocukların sosyal beceri davranışları konusunda desteklenmeye ihtiyaçları olduğu görülmektedir.

Velilere, "Sosyal ortamlarda uygun davranışlar sergilemek, çocuğunuzun iletişim becerilerini arttırır mı?” diye soruldu. Bütün veliler iletişim becerilerini arttıracağını, çocukların iletişim kurmadan davranışı öğrenemeyeceklerini ifade etmiştir. Buradan velilerin sosyal davranışlara ve iletişime önem verdikleri görülmektedir.

“Çocuğunuzu sosyal ortamlarda gözlemliyor musunuz?” sorusuna, bütün veliler olumlu yanıt vermiştir. Bu sorudan çocukların velileri tarafından, sosyal ortamlara götürüldükleri anlaşılmaktadır.

“Çocuğunuzu sosyal davranışlar konusunda yeterli görüyor musunuz?” sorusuna yedi veli "ilk girdikleri ortamlarda biraz sıkıntı yaşıyorlar” cevabını vermiştir. Bir veli, çocuğunun yaşıtlarıyla değil, yeni tanıştığı büyüklerin yanında çekindiğini belirtmiştir. Bu yanıtlardan çocukların tanışma, iletişim gibi konularda desteklenmeye ihtiyaçları olduğu sonucuna ulaş1lıştır.

“Çocuğunuz girdiği ortamda hemen arkadaş edinebiliyor mu?” sorusuna yedi veli, başlangiçta çekingen davrandıkları, sonradan arkadaş edindikleri cevabını vermiştir. Buradan, çocukların ilişki başlatma ve sürdürebilme becerileri yönünden desteklenmelerinin gerekli olduğu sonucuna ulaşılmıştır.

“Çocuğunuz arkadaşları tarafindan etkinliklere davet ediliyor mu?” sorusuna, bütün veliler olumlu yanıt vermiştir. Bu yanıttan, çocukların akranları tarafından kabul edilen çocuklar oldukları görülmüştür.

Çalışmadan beklentileri sorulduğunda; çocuklarının sosyal becerilerinde eksiklik varsa bu çalışmada gözlemlenerek giderilmesini, sosyal becerilerinin gelişmesini beklediklerini dile getirerek kendilerinin bu konuda yapabileceklerinin neler olduğunu sormuşlardır. Buradan projede ulaşılmak istenen hedeflerin veliler tarafindan algılanmış olduğu görülmüştür.

Bu görüşmede konuşulmasını beklediğiniz ve konuşmadığımız bir konu var mı? sorusuna karşın, veliler istedikleri zaman proje konusunda lidere danışıp danışamayacaklarını sormuşlardır. Buradan, iletişime açık, çocuklarının gelişimleriyle yakından ilgili veliler oldukları görülmüştür.

\section{İlişki Başlatma Becerilerine İlişkin Bulgular}

Velilerin, uygulamadan önce ve sonra yapılan ilişki başlatma ve sürdürebilme becerileri veli anketi sorularına verdikleri cevapların sonuçları Tablo1'de görülmektedir.

Tablo1. Illişki Başlatma ve Sürdürebilme Becerileri

\begin{tabular}{|l|l|l|l|}
\hline Derecelendirme ifadesi & Ön anket & Son anket & Fark \\
\hline Her zaman & 38 & 133 & +95 \\
\hline Bazen & 146 & 73 & -73 \\
\hline Hiçbir zaman & 40 & 19 & -21 \\
\hline
\end{tabular}


Tablo 1 incelendiğinde; ön anket uygulamasında "her zaman" seçeneği 38 kez, son ankette $133 \mathrm{kez}$ işaretlenmiş olup sonuç olarak, grubun projeden önce sosyal beceriye giren eylemlerden 38“i davranışa dönüşmüşken projeden sonra 95 eylemin daha davranışa dönüştügü görülmüştür. "Bazen" seçeneği ön anket uygulamasında $146 \mathrm{kez}$, son ankette $73 \mathrm{kez}$ işaretlenmiş ve projeden önce sosyal beceriye giren eylemlerden 146'sı bazen davranışa dönüşmüşken, projeden sonra 73'ünün her zaman davranışa dönüştüğü görülmüş̧ür. "Hiçbir zaman" seçeneği ön anket uygulamasında $40 \mathrm{kez}$, son ankette $19 \mathrm{kez}$ işaretlenmiş ve projeden önce hiçbir zaman davranışa dönüşmeyen sosyal beceriye giren eylemlerden 19'unun olumlu yönde davranışa dönüştüğü görülmüştür.

\section{Atölye Gözlemlerine İlişkin Bulgular}

1. Oturum: "Beden dilini kullanır, grupla etkileşimi sağlar, bireysel farklılıkların farkına varır” kazanımları çerçevesinde yapılan gözlemler şöyledir: Çocukların drama ile ilgili hazır bulunuşluk düzeyleri yeterliydi. Atölye süresince çalışmalardan keyif aldıkları gözlendi. Çocuklar aynı okulda, farklı sınıflarda okuyan arkadaşlar oldukları için ısınma çalışmalarının rahat bir şekilde ilerlediği gözlemlenmiştir. Etkinlikler sırasında, grup etkileşiminin sağlandığı, beden dillerini kullanmada rahat oldukları gözlenmiştir. Atölyenin başında, sorulan sorulara cevap vermeleri için desteklenmeleri gerekmiştir. Atölyenin sonunda, sorulara cevap verme konusunda daha iyi oldukları görülmüş̧ür. Çocukların atölyenin başındaki davranışlarıyla, sonundaki davranışları arasında, olumlu yönde farkl11ık gözlenmiştir. Bu gözlem sonucunda, tanışma, iletişim, etkileşim konu başlıklı birinci atölyenin amacına hizmet ettiği düşünülmektedir. Çocuklar, her ne kadar drama geçmişi olan çocuklar olsa da, süreçsel bir yaklaşımla yapılandırılmış drama çalışması olarak ilk deneyimleridir. Bu nedenle ilk atölyelerde, "ne zaman drama yapacağız" sorusu ile karşılaşılmıştır.

2. Oturum: "Yönerge verir, verilen yönergelere uyar" kazanımları çerçevesinde yapılan gözlemler şöyledir: Çocukların atölyenin başında yönerge verirken ve yönerge alırken, desteklenmeye ihtiyaçları olduğu, atölye sonunda ise desteğe ihtiyaç duymadıkları gözlendi. Bu gözlem sonucunda, kazanımları doğrultusunda ikinci atölyenin amacına ulaştığı düşünüldü.

3. Oturum: "Yeni bir kişiyle tanışma becerisi gelişir, tanıştığ 1 kişi ile etkileşim içinde olmanın önemini kavrar" kazanımları çerçevesinde yapılan gözlemler şöyledir: Atölye kazanımlarının, çocuklar tarafından gösterildiği gözlendi. Kendilerini tanıttıkları, devi kasabalılara tanıştırdıkları ve devle birlikte, yeni tasarladıkları oyunlarını oynarken etkileşim içinde oldukları görüldü.

4. Oturum: "Lideri ve arkadaşlarını dinler, dinlemenin ve dinlenilmenin önemli olduğunun farkına varı, anlamadığı konularda soru sorar, bedenini ve mimiklerini kullanır” kazanımları çerçevesinde yapılan gözlemler şöyledir: Bu oturumda, çocukların istenilen davranışları atölye sonunda gösterdikleri gözlendi. Bu durum da atölyenin amacına ulaştı̆̆ını göstermektedir.

5. Oturum: "Konuşmayı başlatır, kendini sözel olarak ifade eder, grup içinde konuşma becerisi gelişir” kazanımları çerçevesinde yapılan gözlemler şöyledir: Atölyenin, kullanılan hayvan maskeleri, yıldız kuklayla, oldukça renkli, hareketli ve eğlenceli geçtiği gözlendi. Bir çocuğun "Bu drama çok kısaydı" sözünden, eğlenir ve üretirken zamanın nasıl geçtiğini fark etmedikleri, aksesuar kullanımının katılımı olumlu yönde etkilediği gözlendi. Atölye sırasında çocukların grupça çalıştıkları, kendilerini ifade etmede sorun yaşamadıkları gözlendi. Bu durum atölyenin kazanımlarına hizmet ettiği sonucunu düşündürdü. 
6. Oturum: "Yardım ister, yardım istendiğinde yardım eder, yardım etme ve istemenin önemini kavrar, bir gruba katılma becerisi gelişir" kazanımları çerçevesinde yapılan gözlemler şöyledir: Atölyede yapılan etkinliklerin kazanımlara yönelik olduğu, bir veya iki etkinliğin daha yapılabileceği, zamanın buna göre ayarlanabileceği ve bu sayede kazanımların daha fazla desteklenebileceği düşünüldü.

7. Oturum: "Başkalarını tanıtır, kendini tanıtır, ikna etme becerisi gelişir" kazanımları çerçevesinde yapılan gözlemler şöyledir: Atölye genel olarak hareketli ve eğlenceliydi. Çocuklar atölyenin kazanımlarını gösterebildiler.

8. Oturum: "Gerekli durumlarda teşekkür eder, gerekli durumlarda özür diler, beğendiği bir durumda iltifat eder" kazanımları çerçevesinde yapılan gözlemler şöyledir: Atölye sonunda, çocuklardan bazılarının lidere teşekkür ettiği, bunu gören diğer çocukların da aynı davranışı gösterdikleri gözlendi. Atölyenin, gerekli durumlarda teşekkür eder, gerekli durumlarda özür diler, kazanımlarının çocuklarda var olduğu, bu atölye ile pekiştirildiği düşünüldü. İltifat etme kazanımını, çocuklar gösterdiler.

9. Oturum: "İlişki başlatma ve sürdürebilme becerileri gelişiri." kazanımı çerçevesinde yapılan gözlemler şöyledir: Atölye tüm sürecin tekrarı niteliğindeydi. Yapılan etkinliklerde, çocukların önceki atölyeleri hatırlayıp, aynı çalışmaları yaptıkları gözlendi. Bu oturumda farklı etkinlikler kullanılarak, atölye daha fazla renklendirilebilir diye düşünüldü. Çocukların yaratıcı drama geçmişleri olduğu için, sürece aktif katılım göstererek üretken oldukları gözlendi.

\section{Sonuç ve Öneriler}

Yaratıcı dramanın birçok alanda ne kadar etkili bir yöntem olduğu bu zamana kadar yapılmış çalışmalarla ortaya konmuştur. Çalışmada yer alan çocukların, önceden olumlu drama yaşantılarının olduğu, atölyeler sonunda ise düşüncelerinin pekiştiği, sosyal becerilerin yaratıcı drama yöntemiyle işlenmesinin, çocuklar üzerinde olumlu sonuçlar doğurduğu gözlenmiştir. Velilere uygulamadan önce ve sonra yapılan ilişkiyi başlatma ve sürdürebilme becerileri, anketinin sonuçlarına bakıldığında, çocukların becerilerinde olumlu değişimler olduğu görülmüştür.

Odak grup görüşmesinde, çocukların girdikleri sosyal ortamlarda çekingen tavırlarının olduğu konuşulmuş, uygulama süreci ve sonrasında, velilerle görüşülerek, bu davranışın daha kısa süreli olduğunun gözlemlendiği öğrenilmiştir. Ayrıca, bulundukları sosyal ortamlarda, proje öncesine göre daha aktif oldukları belirtilmiştir. Bu durum da projenin, çocukların, ilişki başlatma ve sürdürebilme, becerilerinde olumlu etkilerde bulunduğunu göstermektedir.

Atölyeler sırasında tutulan öğretmen gözlem kayıtlarında, atölyelerin kazanımlarının çocuklar tarafından gösterildiği, böylece projenin amacına ulaştığı görülmüştür. Atölyelerin sonunda çocukların sosyal becerilerden ilişki başlatma ve sürdürebilme becerileri olan; dinleme, konuşmayı başlatma, konuşmayı sürdürme, soru sorma, teşekkür etme, kendini tanıtma, başkalarını tanıtma, iltifat etme, yardım isteme, bir gruba katılma, yönerge verme, yönergelere uyma, özür dileme, ikna etme becerilerine ilişkin, sosyal ortamlarda uygun davranışlar sergileme düzeylerinin, sosyal davranışlar konusunda farkındalıklarının arttığı, özetle projenin hedeflerini gerçekleştirdiği görülmüştür.

Bugüne kadar sosyal becerilerle ilgili çok fazla çalışma yapılmış olmasına rağmen, bu alanda yöntem olarak yaratıcı dramanın az kullanılmış olması ve sosyal becerilerden ilişki başlatma ve 
sürdürebilme becerileri gibi önemli bir konunun yaratıcı drama yöntemi ile incelenmesi projenin önemini bir kat daha arttırmaktadır. Bu ve buna benzer yapılacak olan çalışmaların okul öncesi çocuklarında, sosyal beceri davranışlarının kalıcı olmasını sağlayacağı, bu tür çalışmaların, ilgililer tarafindan er ya da geç fark edileceği ve uygulamada yer alacağı kaçınılmaz bir sonuçtur. Her ne kadar atölyeler drama yaşantısı olan çocuklarca gerçekleştirilmiş olsa da, sosyal becerilerle ilgili projelerin yaratıcı drama yöntemi uygulanarak drama yaşantısı olmayan bireylerde de olumlu sonuçlar doğurabileceği düşünülmektedir.

Çalışmanın yapılacağı grubun hazır bulunuşluklarının etkinliklerin sürelerini etkileyebildiği gözlemlenmiştir. Atölye çalışmasından önce, çocukların hazır bulunuşluk seviyelerinin belirlenmesi, bunlar göz önünde bulundurularak etkinliklerin sadeleştirilmesi veya arttırılmasının uygulayıcıyı, istenilen hedefe daha hızlı ve sorunsuz götürebileceği düşüncesini doğurmuştur.

Liderin role girmesi çalışmalarında, çocukların bazılarının liderin yeni rolünü özümsemekte zorluk yaşadığ atölyenin başında, çocuklara -mış gibi yapmak kavramını açıklaması ve liderin rolde olduğunun göstergelerine yer vermesi önerilir.

Sosyal becerilerden sadece ilişki başlatma ve sürdürebilme becerileri değil, bütün sosyal beceriler (grupla bir işi yürütme becerisi, duygulara yönelik beceriler, saldırgan davranışlar ile başa çıkma becerileri, stres durumlarıyla başa çıkma becerileri, plan yapma ve sorun çözme becerileri),yaratıcı dramanın uygulama alanı içerisinde daha fazla yer almalıdır.

\section{Kaynakça}

Adıgüzel, H. Ö. (2006).Yaratıcı drama kavramı, bileşenleri ve aşamaları. Yaratıcı Drama Dergisi, 1(1), 17-27.

Arnas, Y. A. ve Hasırcı, Ö. K. (2009). Erken çocukluk eğitiminde yaratıcı drama. Adana 14. Uluslararası Eğitimde Yaratıcı Drama Semineri.

Aslan, E. (2008). Drama temelli sosyal beceri eğitiminin 6 yaş çocuklarının sosyal ilişkiler ve işbirliği davranışlarına etkisi. Yüksek lisans tezi, Adnan Menderes Üniversitesi Sosyal Bilimler Enstitüsü, İlköğretim Ana Bilim Dalı, Aydın.

Avcıŏlu, H. (2007). Etkinliklerle sosyal beceri ögretimi. Ankara: Kök Yayıncılık.

Berns, R. M. (1989). Child, family, community, Mat Rinehart And Winston Inc., 257.

Cerrahoğlu, S. (2002). Sosyal beceri eğitiminin ilköğretim çocularinin öz kavramı düzeylerine etkisi. Yayımlanmamış yüksek lisans tezi, Ondokuz Mayıs Üniversitesi Sosyal Bilimler Enstitüsü Eğitim Bilimleri Ana Bilim Dalı, Samsun.

Çiftci, İ. ve Sucuoğlu, B. (2009). Bilişsel süreç yaklaşımıyla sosyal beceri öğretimi. Ankara: Kök Yayıncılık.

Çubukçu, Z. ve Gültekin, M. (2006). İlköğretimde çocuklara kazandırılması gereken sosyal beceriler. Bilig. Bahar, 37, 161-168. http://yayinlar.yesevi.edu.tr/files/article/25.pdf

Öztürk, A. (Edt.) (2006). Çocukta yaratıcılık ve drama. Eskişehir: Anadolu Üniversitesi Yayınları.

Öztürk, A. (Edt.) (2007). Dramada öğrenme ve öğretme süreci: İlköğretimde drama, Eskişehir: Anadolu Üniversitesi Yayınları.

Erbay, E. (2008). Okul öncesi eğitim alan ve almayan ilköğretim birinci slnıf çocularinin sosyal becerilere sahip olma düzeyleri. Yayımlanmamış yüksek lisans tezi, Pamukkale Üniversitesi Sosyal Bilimler Enstitüsü, Denizli.

Eti, İ. (2010). Drama etkinliklerinin okul öncesi eğitim kurumlarına devam eden 5-6 yaş grubu çocukların sosyal becerileri üzerine etkisi. Yayımlanmamış yüsek lisan tezi, Çukurova Üniversitesi Sosyal Bilimler Enstitüsü Okul Öncesi Eğitim Anabilim Dalı, Adana. 
Gökbulut, Ö. Ö. (2005). Çocukluğu ve büyüklü̆̆̈̈ anlamak anne baba farkındalığı gelişiminde yaratıcı drama yönteminin kullanılmasl. Ankara Üniversitesi Eğitim Bilimleri Enstitüsü, Yaratıcı Drama Tezsiz Yüksek Lisans Programı bitirme projesi.

Gresham, F.M.\& Elliot, S. N. (1987). The relationship between adaptive behavior and social skils: Issuues in definition and assesment. The Journal of Special Education, 21(1), 167-181.

Kurt, F. (2007). Okul öncesi eğitim kurumlarına devam eden beş-altı yaş çocuklarının sosyal uyum ve becerilerine proje yaklaşıml eğitim programlarının etkisinin incelenmesi. Yayımlanmamış yüksek lisans tezi, Gazi Üniversitesi Eğitim Bilimleri Enstitüsü. Çocuk Gelişimi ve Eğitimi Ana Bilim Dalı, Ankara.

San, İ. (2006). Yaratıcıllı̆̆ geliştiren bir yöntem ve yaratıcı bireyi yetiştiren bir disiplin eğitsel yaratıcı drama. H.Ö. Adıgüzel (Ed.). Yaratıcı Drama 1985-1998 Yazllar (2.bs.), (ss.342-363). Ankara: Naturel Yayınc1lık.

Şen, C. (2001). Yaratıcı dramanın PDR alanıyla iliş̧kisnin incelenmesi. Uludağ Üniversitesi Eğitim Bilimleri Bölümü Rehberlik ve Psikolojik Danışmanlık Ana Bilim Dalı, Bursa.

Üstündağ, T. (2006). Yaratıcı drama öğretmenimin günlüğ̈̈ (7.bs.). Ankara: Pegem-A yayınc1lık. 